\title{
Are Foreign Cultures InTEResting for EU Citizens? COMParative Study aCross EU MEMber COUNTRIES
}

\author{
Eva Ardielli \\ VSB - Technical University of Ostrava, \\ Faculty of Economics, Department of Public Economics, \\ Sokolská tř́da 33, 70200 Ostrava 1, Czech Republic \\ e-mail: eva.ardielli@vsb.cz
}

\begin{abstract}
Culture is one of Europe's greatest strengths. It contributes to people's well-being, to social cohesion and inclusion. Cultural and creative sectors are considered as very important at EU level. They are considered as drivers of economic growth, job creation and external trade. The EU is diverse in cultural matters and the EU member countries are different with diverse culture backgrounds. The article is focused on the issue of participation of EU citizen in foreign cultures. The willingness of EU citizens to participate in foreign cultures across EU member countries is evaluated based on the indicators describing the level of foreign languages knowledge and the participation in foreign cultural products as the expression of interest and openness to foreign cultures. The evaluation was performed by means of WSA method.
\end{abstract}

\section{Keywords}

Assessment; Culture; European Union; Language skills, Weighted sum approach.

\section{Introduction}

Culture is an important topic of the present time. As evidenced by UNESCO (2002), culture is at the heart of contemporary debates about identity, social cohesion, and the development of a knowledge-based economy. The international organizations (like UNESCO, OECD, Council of Europe) are affirming that respect for the diversity of cultures, tolerance, dialogue and cooperation, in a climate of mutual trust and understanding, are among the best guarantees of international peace and security. Culture should be regarded as the set of distinctive spiritual, material, intellectual and emotional features of society or a social group, that encompasses, in addition to art and literature, also lifestyles, ways of living together, value systems, traditions and beliefs [17].

Culture is becoming increasingly important also at EU (European Union) level. In accordance with Article 167 of the Lisbon Treaty, "the EU shall contribute to the flowering of the cultures of the member states, while respecting their national and regional diversity and at the same time bringing the common heritage to the fore". Therefore, culture is an important aspect of EU policy. However, it is considered also as a driving force for economic development, as well as innovation. As stated by Eurostat [5] culture is one of Europe's greatest strengths: "it is a source of values and identity and gives the continent a sense of belonging". It also contributes to people's well-being, to social cohesion and inclusion. In our increasingly diverse societies it is essential to ensure harmonious interaction among people and groups with plural, varied and dynamic cultural identities as well as their willingness to live together. Policies of inclusion and participation of all citizens are therefore guarantees of social cohesion, the vitality of civil society and peace, see [17]. 
The main EU's cultural priorities are to contribute to the development of the culture in the EU member countries, to encourage contemporary cultural production and to promote cultural cooperation and diffusion of culture across EU. Moreover, the issue of cultural cohesion and multiculturalism is very topical in the contemporary, rapidly changing environment as well. Currently we are experiencing a number of manifestations of insufficient cultural integration in today's highly differentiated European societies.

\subsection{Cultural Pluralism and Multiculturalism}

Cultural pluralism is a term used when smaller groups within a larger society maintain their unique cultural identities, and their values and practices are accepted by the wider culture. Cultural pluralism is distinct from multiculturalism [12]. Multiculturalism lacks the requirement of a dominant culture. If the dominant culture is weakened, societies can easily pass from cultural pluralism into multiculturalism without any intentional steps being taken by that society. If communities function separately from each other, or compete with one another, they are not considered culturally pluralistic [13]. Cultural pluralism seeks, on the one hand, the conditions and limits of peaceful coexistence of different cultures, but also examines the unexpected advantages of such cultural diversity. Historical and empirical studies show that culturally mixed society in the cities or in the border areas have been exceptionally productive, see [10], [1]. The task of cultural pluralism is therefore to explore and apply the conditions of fruitful communication among diverse cultural groups, to draw attention to the advantages and risks of culturally inhomogeneous societies and to promote cultural and intellectual exchanges between them. The basic conditions include knowledge of a common language, fundamental recognition of the other, and finally the discovery of its potential importance and benefit to the majority society [9]. Multiculturalism is the school of thought and political stream, which is of the opinion that in a democratic state not only individuals but also groups with different cultures can live and which highlights the benefits of cultural diversity for society and the state. It is applied in countries whose residents come from different cultural backgrounds and in some of them is also applied as a specific policy of the state. The aim is to unite politically all citizens, regardless of their origin, ethnicity or belief, so as to preserve their cultural differences if possible, as stated by Wayland [18] or White [19].

\subsection{Language Diversity in European Union}

Language diversity across EU is great. In EU, there are 24 official languages. According to the Council of Europe [4] in their daily lives, Europeans increasingly come across foreign languages. There is therefore a need to generate a greater interest in languages among European citizens. Due to the influx of migrants and refugees, Europe has become largely multilingual. For example in London alone some 300 languages are spoken (Arabic, Turkish, Kurdish, Berber, Hindi, Punjabi, etc.). According to Eurostat [7] that contains information on foreign language skills in EU, in many EU member countries more than 9 out of 10 pupils in lower secondary education study two or more foreign languages. For example in Luxembourg it is $100 \%$ of pupils, in Finland 98\%, in Greece 97\%, in Italy 96\%, in Estonia and Romania 95\%. The EU average is 59\%. In the Czech Republic 65\% of pupils study two or more foreign languages. The lowest share of pupils studying two or more foreign languages in EU member countries is in Ireland (13\%), Austria (9\%) and Hungary (6\%). Not surprisingly, English is by far the foreign language most studied in the EU. 97\% of pupils studied English in lower secondary education in 2015, followed by French (34\%) and German (23\%). However, in some Member States English was not the main foreign language to be studied. This was the 
case of Belgium (French was the first foreign language), Ireland (French), Luxembourg (German).

\subsection{Cultural Participation in European Union}

Cultural participation is an essential dimension of personal well-being and integration of individuals in society [5] According to the Council of Europe, the right to take part in cultural life is - and shall be recognised as being - pivotal to the system of human rights [3]. Participation in cultural activities and in cultural products is a fundamental human behaviour and is promoting human well-being [2], [14]. Wider participation in cultural life is a major concern of national cultural policies in different countries around the world [3]. Cultural practices can be defined according to three categories, see [11]: home-based (watching TV, listening to the radio, reading books and newspapers, watching and listening to recorded sound and images, reading and using computer and the Internet), going out (visits to cultural venues such as cinema, theatre, concerts, museums, monuments and heritage sites) and identity building (covers amateur cultural practices, membership of cultural associations, popular culture, ethnic culture, community practices and youth culture).

Nevertheless, according to studies of European Commission from 2007 and 2013, see [16], the cultural participation is decreasing in the EU. For example the share of readers fell from 2007 to 2011 by 10 percentage points (the indicator Number of books read in the last 12 months), see [6]. Moreover, the statistical data document the new trend on EU book market increasing share of e-books and decreasing trend of printed books. Also going to the cinema and visiting live performances is significantly influenced by the entry of ICT. The main reasons to non-participation in cultural activities are, according to Eurobarometer survey, see [16], lack of interest, lack of time and expense. Also only small minorities of Europeans participate in cultural activities and in cultural products from another European country, and even fewer participate in activities in another EU country. The most commonly accessed activity is reading books by an author from another European country (31\% of Europeans have done so at least once in the last 12 months), followed by watching or listening to a cultural TV or radio programme from another European country $(27 \%)$. Fewer Europeans participate in cultural activities in another EU country: $19 \%$ have visited a historical monument or site and $10 \%$ have attended a live performance, exhibition or cultural activity.

\section{Problem Formulation and Methodology}

The article deals with the issue of the participation of EU citizen in foreign cultures. The intention is to assess the attitude of EU citizens to foreign cultures. The expression of interest and openness to foreign cultures can be demonstrated by the effort of citizens to learn foreign languages and to participate in foreign cultural products. As a cultural product, the art and cultural heritage and everything associated with it is referred to. For example, traditional arts (like writing, painting, sculpture and dance), theatres, museums, galleries, monuments, exhibitions, individual exhibits and accompanying services, all of these can be described as cultural products [8]. Cultural product is also the output of cultural-products industries (service outputs that focus on entertainment - motion pictures, recorded music and print media, etc.).

\subsection{Aims of the Research}

The aim of the article is to evaluate the EU member countries in the area of foreign language knowledge and participation in foreign cultural products, by usage of multi-criteria decision making methods. The results of the research are pointing out the differences among EU member countries, concerning the attitude of citizens to participate in foreign culture. The 
problem was solved by usage of multi-criteria decision-making model. The purpose of these models is either to find the best variation of all considered considerations, to exclude ineffective variants or to arrange a set of variants, see [15].

In this article the multi-criteria decision-making model was used to the arrangement of the variants. The elements of the model of multi-criteria analysis of variants were:

- variants of decisions $a_{i}, i=1, \ldots, m$ (28 EU member countries)

- criteria $f_{j}, j=1, \ldots, n$ by which variants are evaluated (14 indicators)

- evaluation of variations according to individual criteria $y_{i j}, i=1, \ldots, m, j=1, \ldots, n$

- preference of criteria $v_{j}, j=1, \ldots, n$, expressing their importance

Criteria weights were determined based on the scoring method. This is the most commonly used method that transforms the point assessment of the importance of the criteria into the form of the weighting vector.

\section{$2.2 \quad$ Method}

The designed multi-criteria decision-making model was solved by means of WSA method. The WSA method (Weighted Sum Approach) requires cardinal information, cardinal matrix $Y$ and vector of criteria weights $v$. The output of WSA is an overall rating for each variant and can be used to organize variants from the best to the worst. WSA method is based on linear utility function. It is based on the principle of utility maximization. If the variant $a_{i}$ reaches according to criterion $j$ the certain value $y_{i j}$, it gives the user the utility that can be expressed using a linear function of utility. The total utility of the variant is expressed by the weighted sum of the values of the partial utility functions, see formula (1):

$$
u\left(a_{i}\right)=\sum_{i=1}^{m} v_{j} \cdot u_{j}\left(y_{i j}\right)
$$

where $u_{j}$ are partial functions of utility of individual criteria and $v_{j}$ are criteria weights. The algorithm of the WSA method consists of three steps. First is the ideal variant $H$ with evaluation $\left(h_{1}, \ldots, h_{n}\right)$ and basal variant $D$ with evaluation $\left(d_{1}, \ldots, d_{n}\right)$. Then a standardized criteriamatrix $R$ is obtained, the elements of which are obtained by the formula (2):

$$
r_{i j}=\frac{y_{i j}-d_{j}}{h_{j}-d_{j}}
$$

The matrix $R$ is already the value matrix of utility function of the $i$-th variant of the $j$-th criterion because the elements of this matrix are transformed criteria values such as $r_{i j} \in$ $\langle 0 ; 1\rangle$. Then the basal variant corresponds to value 0 and the ideal variant to value 1 . Finally, the aggregate utility function is calculated for each variant, see formula (3):

$$
u\left(a_{i}\right)=\sum_{j=1}^{n} v_{j} r_{i j}
$$

Then the variants are sorted in descending order according to values $u\left(a_{i}\right)$.

\subsection{Data}

In this article the evaluation of language skills of EU citizens in individual EU member countries and evaluation of participation in foreign culture products was performed. The evaluation of language skills was based on 7 indicators (criteria) available from the Eurostat 
database - Adult Education Survey (AES), see [7]. AES is a source of data on the knowledge of languages by the adult population (self-reported competencies). The survey focused on people aged 25-64 living in private households and the reference period was the 12-months prior to the respondent's interview. This unique dataset enabled the reliable analysis of foreign language knowledge because it contains comparable data of all $28 \mathrm{EU}$ member countries based on the results of questionnaire from the year 2016.

The evaluation of the cultural participation of EU citizens on foreign cultural products was carried out on the basis of 7 cultural indicators which had been obtained in the framework of the Eurobarometer survey [16]. The European Commission's Directorate-General for Education and Culture (DG EAC) commissioned this survey in an effort to measure the attitudes of the European public to individual cultural activities. The survey involved a total of 27,563 European citizens from all $28 \mathrm{EU}$ member countries. The last available data refer to the year 2013.

\section{$3 \quad$ Problem Solution}

Multi-criteria decision-making models show decision-making issues where the consequences of decisions are judged by multiple criteria. Multi-criteriality characterizes almost every decision-making situation. In these models of multi-criteria analysis of variants, a final set of variants is given, which is evaluated according to selected criteria. In the research, there was selected the final list of variants, which were $28 \mathrm{EU}$ member countries and two sets of criteria. 7 criteria for evaluation of language skills (different weights for individual criteria - in total $0.5)$ :

- Number of foreign languages known - no languages (weight 0.11842);

- number of foreign languages known - 1 language (weight 0.02632);

- number of foreign languages known - 2 languages (weight 0.06579);

- number of foreign languages known - 3 languages or more (weight 0.11842 );

- level of the foreign language reported as best-known - proficient (weight 0.11842);

- level of the foreign language reported as best-known - good (weight 0.03948);

- level of the foreign language reported as best-known - basic (weight 0.01316);

and 7 criteria for evaluation of foreign cultural participation (the same weight 0.07142 for all criteria - in total 0.5 ):

- Visit of ballet, dance performance or opera from another EU country;

- visit of theatre performance from another EU country;

- visit of musical performance (concert, band, etc.) from another EU country;

- watching/listening to cultural programme on TV/radio from another EU country;

- reading a book by an author from another EU country;

- visit of historical monument/site (palaces, castles, etc.) in another EU country;

- attending live performance, festival or cultural activity in another EU country.

The input data were processed by WSA method. The output of WSA method is the arrangement of variants from the best to the worst according to the value of utility $u\left(a_{i}\right)$. In Table 1 it is possible to see the final order of variants according to the selected criteria. 
Tab. 1: Ranking of EU member countries according to participation in foreign cultures

\begin{tabular}{|l|l|l|l|l|l|}
\hline Position & Variant & Utility & Position & Variant & Utility \\
\hline 1 & Luxembourg & 0.87589 & 15 & Cyprus & 0.38558 \\
\hline 2 & Sweden & 0.72084 & 16 & Czech Republic & 0.31929 \\
\hline 3 & Denmark & 0.65310 & 17 & Croatia & 0.31128 \\
\hline 5 & Netherlands & 0.62447 & 18 & Ireland & 0.30942 \\
\hline 6 & Finland & 0.59499 & 19 & France & 0.29087 \\
\hline 7 & Malta & 0.56789 & 20 & Hungary & 0.22026 \\
\hline 8 & Austria & 0.56521 & 21 & Greece & 0.21711 \\
\hline 9 & Slovakia & 0.55514 & 22 & Portugal & 0.21280 \\
\hline 10 & Belgium & 0.50702 & 23 & Spain & 0.21209 \\
\hline 11 & Slovenia & 0.48060 & 24 & United Kingdom & 0.20720 \\
\hline 12 & Estonia & 0.46140 & 25 & Italy & 0.20649 \\
\hline 13 & Lithuania & 0.45100 & 27 & Poland & 0.17846 \\
\hline 14 & Germany & 0.44416 & 28 & Romania & 0.08631 \\
\hline
\end{tabular}

Source: Author's calculations, [7], [16]

On the top positions are placed the EU member countries that reached the best result (Luxembourg, Sweden, Denmark, Netherlands, and Finland). It means that the citizens of these countries were evaluated as most skilled with knowledge of foreign languages and most interested in foreign cultures. The Czech Republic ranked on the 16th position. United Kingdom, Italy, Bulgaria, Poland and Romania (28th position) ranked among the worst. It means that the level of language skills and participation in foreign cultural products in these countries is the lowest across EU member countries.

\section{Conclusion}

Cultural, religious and linguistic diversity are, at first glance, obstacles to communication and clearly complicate social life. But closer study reveals that if these diverse segments of society learn to communicate, it brings unexpected benefits to the majority and minorities. Conversely, if the different cultures only live side by side, avoiding contacts and simply "tolerate" themselves, this represents a certain danger that in a crisis can erupt in violence.

The article was focused on the evaluation of EU member countries according to the citizens' attitude to the knowledge of foreign languages and consumption of foreign culture products. The EU member countries were ranked based on 14 selected criteria by usage of MCDM method WSA. It confirmed the diversity across EU member countries in terms of willingness of citizens to participate in foreign culture. The most inclined to use foreign languages and to consume foreign culture products are the Luxembourgers, Swedes, Danish, Dutchmen and Finns. On the other hand the British, Italians, Bulgarians, Poles and Romanians are less keen to get to know foreign languages and cultures. Europe is facing the process of globalization that involves mixing of different cultures. The trend of the present day is also the rapid development of new information and communication technologies. All these things represent 
a challenge for cultural diversity and create the conditions for a renewed dialogue among cultures and civilizations.

\section{Acknowledgements}

This article was created within the financial support of the student grant project SGS No. SP2017/129 Economic Factors Affecting the Ensuring of Public Services with Collective Consumption on Faculty of Economics, Technical University of Ostrava.

\section{Literature}

[1] ANGHEL, F.: Adult Education, Democracy and Development. [online]. 1994. Strasbourg. https://katalog.npmk.cz/documents/36588?locale $=\mathrm{cs}$

[2] BROOK, O.: International comparisons of public engagement in culture and sport. [online]. London: DCMS, 2011. [accessed 2018-02-14]. Available from WWW: https://www.gov.uk/government/uploads/system/uploads/attachment_data/file/77843/In t_comparisons_public_participation_in_culture_and_sport-Aug2011.pdf

[3] COMPENDIUM: Compendium of Cultural Policies and Trends in Europe. [online]. 2017. http://www.culturalpolicies.net/web/cultural-participation.php

[4] COUNCIL OF EUROPE: Language Facts. [online]. 2018. https://edl.ecml.at/LanguageFun/LanguageFacts/tabid/1859/language/en-

GB/Default.aspx

[5] EUROSTAT: $\quad$ Culture $\quad$ statistics 2016. http://ec.europa.eu/eurostat/documents/3217494/7551543/KS-04-15-737-EN-N.pdf

[6] EUROSTAT: Digital economy and society statistics - households and individuals. [online]. $2016 . \quad$ http://ec.europa.eu/eurostat/statisticsexplained/index.php/Digital_economy_and_society_statistics_households_and_individuals

[7] EUROSTAT: Statistics on Education [online]. 2018. http://ec.europa.eu/eurostat/statisticsexplained/index.php/Foreign_language_skills_statistics

[8] JOHNOVÁ, R., et al.: Arts Marketing, Marketing umění a kulturního dědictví. Oeconomia, Praha, 2009. ISBN 978-80-245-1276-1.

[9] KALLEN, H. M.: Culture and Democracy in the United States. Boni Liveright, New York, 1924. ISBN 9781560009665.

[10] KALLEN, H. M.: Pluralism and American Jewish Identity. American Jewish History. DOI: $10.1353 /$ ajh.1997.0007

[11] MORRONE, A.: Guidelines for Measuring Cultural Participation. [online]. Quebec: UNESCO Institute for Statistics, 2006. [accessed 2018-03-14]. Available from WWW: http://uis.unesco.org/sites/default/files/documents/guidelines-for-measuring-culturalparticipation-2006-en.pdf

[12] NAGLE, J.: Multiculturalism's double bind: creating inclusivity, cosmopolitanism and difference. Ashgate Publishing, Ltd, Farnham, 2009. ISBN 978-0754676072.

[13] PANTOJA, A.; PERRY, W.; BLOUROCK, B.: Towards the Development of Theory: Cultural Pluralism Redefined. The Journal of Sociology \& Social Welfare. 1976, Vol. 4, Issue 1, pp. 125-146. ISSN 0191-5096. 
[14] SCHUSTER, J. M.: Participation Studies and Cross-National Comparison: Proliferation, Prudence, and Possibility. Cultural Trends. DOI: $\underline{10.1080 / 09548960701299815}$

[15] ŠUBRT, T. et al.: Ekonomicko-matematické metody. Aleš Čeněk, s.r.o., Plzeň, 2015. ISBN 978-80-7380-563-0.

[16] TNS OPINION \& SOCIAL: Cultural Access and Participation. Special Eurobarometer 399. [online]. Brussels: European Commission, 2013. [accessed 2018-01-04]. Available from

WWW: http://ec.europa.eu/commfrontoffice/publicopinion/archives/ebs/ebs_399_en.pdf

[17] UNECSO: Universal Declaration on Cultural Diversity. [online]. 2002. http://unesdoc.unesco.org/images/0012/001271/127162e.pdf

[18] WAYLAND, S.: Immigration, Multiculturalism and National Identity in Canada. International Journal of Minority and Group Rights. DOI: $\underline{10.1163 / 15718119720907408}$

[19] WHITE, R.; PERRONE, S.: Racism, Ethnicity and Hate Crime. Communal/Plural. DOI: $\underline{10.1080 / 13207870120081479}$ 


\section{ZAJÍMAJÍ SE OBČANÉ EU O ZAHRANIČNÍ KULTURU? SROVNÁVACÍ STUDIE V ČLENSKÝCH ZEMÍCH EU}

Kultura je jednou z nejsilnějších stránek Evropy. Přispívá k blahu lidí, sociální soudržnosti a inkluzi. Sektor kultury a tvưrčích odvětví je na úrovni EU považován za velmi důležitý. Představuje hnací sílu pro hospodářský růst, tvorbu pracovních míst a zahraniční obchod. EU je rozmanitá v oblasti kultury a členské státy EU se kulturně výrazně odlišují. Článek je zaměřen na problematiku participace občanů EU na zahraniční kultuře. Ochota občanů EU, participovat na zahraniční kultuře $\mathrm{v}$ jiných členských státech EU, je zhodnocena na základě ukazatelů, popisujících úroveň znalostí cizích jazyků a participaci na zahraničních kulturních produktech, jako projevu zájmu a otevřenosti k cizím kulturám. Hodnocení je provedeno pomocí metody WSA.

\section{SIND DIE EU BÜRGER INTERESSIERT AN DER AUSLÄNDISCHEN KULTUR? VERGLEICHSSTUDIE IN DEN MitGLIEDSTAATEN DER EU}

Kultur ist einer der stärksten Aspekte Europas. Kultur trägt zum Wohl der Menschen, zum sozialen Zusammenhalt und zur Integration bei. Der Sektor der Kultur- und Kreativwirtschaft wird auf EU-Ebene als sehr wichtig angesehen. Es ist eine treibende Kraft für das Wirtschaftswachstum, die Schaffung von Arbeitsplätzen und den Außenhandel. Die EU ist kulturell unterschiedlich und auch die EU-Mitgliedstaaten sind kulturell deutlich unterschiedlich. Der Artikel konzentriert sich auf die Frage nach der Beteiligung von EUBürgern an ausländischer Kultur. Die Bereitschaft der EU-Bürger, sich in anderen EUMitgliedstaaten an der fremden Kultur zu beteiligen, wird anhand von Indikatoren bewertet, die das Niveau der Fremdsprachenkenntnisse und die Teilnahme an ausländischen Kulturprodukten als Ausdruck von Interesse und Offenheit gegenüber fremden Kulturen beschreiben. Die Auswertung erfolgt mit Hilfe der WSA-Methode.

\section{CZY MIESZKAŃCY UE INTERESUJĄ SIĘ KULTURĄ ZAGRANICZNĄ? BADANIA PORÓWNAWCZE W PAŃSTWACH CZŁONKOWSKICH UE}

Kultura jest jednym z najmocniejszych atutów Europy. Przyczynia się do dobrobytu ludzi, spójności społecznej i integracji. Sektor kultury i branż twórczych uważany jest na poziomie UE za bardzo ważny. Kultura jest siłą napędową wzrostu gospodarczego, tworzenia miejsc pracy i handlu zagranicznego. UE jest różnorodna w zakresie kultury, również państwa członkowskie UE znacznie kulturowo się różnią. Artykuł skupia się na kwestii uczestnictwa mieszkańców UE w kulturze zagranicznej. Chęć mieszkańców UE do uczestniczenia w kulturze zagranicznej w innych państwach członkowskich UE oceniana jest na podstawie wskaźników opisujących poziom znajomości języków obcych oraz udział w zagranicznych produktach kulturalnych, traktowanych jako przejaw zainteresowania i otwartości na obce kultury. Ocenę przeprowadzono przy użyciu metody WSA. 